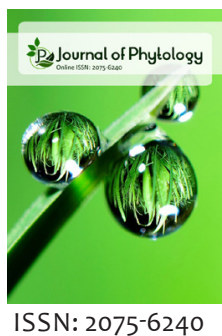

Received: October 12, 2020 Revised: December 09, 2020 Accepted: December 13, 2020 Published: December 27, 2020

Corresponding author:

Oadi Matny,

E-mail: oadi77@yahoo.com

\section{Molecular identification and genetic diversity study of the Iraqi truffles}

\author{
Ammar A. Aish, Saad T. Abdulmalek, Tariq. A. Kareem, Lara B. Yasir, \\ Oadi Matny
}

Department of Plant Protection, College of Agriculture, University of Baghdad, Iraq

\begin{abstract}
The aim of this study is to investigate the molecular identification of the Iraqi truffles species and a better understanding of genetic diversity in the center of the truffles habitat. Thirty-two samples were collected from the Iraqi desert and local markets. Samples were chosen depending on the morphological diversity of the fruit body and sample collection area. Results of ITS region sequencing for the 32 samples showed two genuses Tirmania and Terfezia are the main dominant, 4 species of Tirmania pinoyi and 28 species of Terfezia claveryi. All species sequences were deposited in NCBI GenBank and all had accessions number. The neighbor-Joining method was used to generate a phylogenic tree to study the genetic diversity of the ITS sequences for the 32 Iraqi truffle samples. Results showed a high genetic diversity for the Iraqi truffles samples. The phylogenic study showed Iraqi truffles clustered with different groups as a clade with the reference sequences from other countries represent three continents Asia, Africa, and Europe. Also, we found in this study a unique cluster group for the Iraqi sequences for T. pinoyi and T. claveryi truffles cluster in one group and do not match with any reference sequences used in this study. This is a piece of strong evidence proofed the Iraqi habitat could be the origin of center diversity for the T. pinoyi and T. claveryi truffles.
\end{abstract}

KEYWORDS: Terfezia claveryi, Tirmania pinoyi, PCR, ITS Sequencing, Phylogenic tree

\section{INTRODUCTION}

Historically, the desert truffles have been mentioned in the old ancient manuscripts and Egyptian temples in the Arabian region, also known as a "poor native food as alternative to meat", in Iraq its call kamaa, kima or chima, depending on local dialects [1]. Truffles known as hypogeous ascocarps "grow underground" related Eukaryota; Fungi; Dikarya; Ascomycota; Pezizomycotina; Pezizomycetes; Pezizales; Pezizaceae. Predominantly grow in the desert and live in ectomycorrhizal association with Helianthemum species locally name "Jaraida" [2]. The largest portion of truffles is locally consume, it's have a unique medicinal and organoleptic properties as well as their protein content (20-27\%), and fiber (7-13\%), and fat (3-7.5\%), and ascorbic acid (2-5\%), and also minerals, and $65-67 \%$ carbohydrate [3-5]. It has been reported that Terfezia claveryi and Tirmania nivea occur in deserts of salty and/or gypseous soils [6].

The first scientific reference reported a truffle in Iraq was in 1892 for both Terfezia hafizi the white and Terfezia metaxasias black truffles, made by Chatin [7]. Malencon [8] reported T. claveryi in Iraq. Other study description three species of truffles in Iraq T. claveryi, Tirmania pinoyi and T. nivea [9]. Abdullah et al [10] reported five hypogeous ascomycotina in Iraq Terefezia boudieri,
T. claveryi, Tirmania nivea, T. pinoyi and Phaeangium lefebvrei. In study done by Owaid [11] found two genera of truffles Terefezia and Tirmania depend on the morphological characteristics. In Sulaymaniyah governorate north of Iraq, a study showed only two truffle species T. claveryi and T. boudieri identified using morphological classification [12] (Al-jaff et al, 2018).

All above studies rely on the morphological characteristics to identify truffles. The truffles known to have a wide morphological diversity in color, size and shapes depend on soil type and environment where its grow in the wild, truffle development with fall-winter rainfalls and start to harvest in early spring. The dessert truffles are well distributed around the world, it have been reported in arid and semiarid zones area in different countries, like Iraq and Kuwait, Iran, the Sahara regions of Saudi Arabia and parts of the Magreb [13], Tunisia [14] Algeria[15]. Also in Europe like Hungary and Yugoslavia [16,17], and China [18], the Kalahari Desert $[13,19,20]$, Australia [21,22], and North America [23,24]. Sbissi et al [14] studied genetic diversity of T. boudieri and T. claveryi in Tunisia by using PCR-RFLP technique, and found three haplotype (I, II, and III), the haplotype I was founded in a low $\mathrm{pH}$ soil association with Helianthemum kahiricum. The species from Tirmania and Terfezia is known as mycorrhizal associated with genus 
Helianthemum [25]. A genetic diversity of desert truffles study showed several morphological species by using PCR-RFLP and DNA sequences of (ITS), Terfezia arenaria, T. boudieri, T. claveryi, T. leptoderma, T. terfezioides (= Mattirolomyces terfezioides), Tirmania nivea and T. pinoyi, the phylogenetic analyses showed that both genus Tirmania and Terfezia are genetically closely to each other [26].

The proposed of this study aims to describe the molecular identification of truffle species and distribute in the Iraqi habitat, and understanding the genetic diversity among truffle species in the bioclimatic.

\section{MATERIAL AND METHODS}

\section{Sample Collection}

Samples of truffles were collected from the local markets and desert land known with a natural grow habitat for truffles. Samples collected from these following cities: Alnakhab, Rhatbua, Kahlar, Falluja, Hadeetha, Ana, and Rawa Figure 1. All samples were brought to the plant disease laboratory in the Department of Plant Protection, University of Baghdad. The samples were washed and cleaned with tap water to remove soil. The samples were collected and selected randomly depending on the diversity of color, shapes, and size. All samples were documented with record information of location, collection date, and color. Pictures were taken for the exterior and interior features for the truffle's fruit body. Five grams from each sample were collected with clean knife from the core of the fruit body and kept in $-20{ }^{\circ} \mathrm{C}$ in plastic tubes for use in the DNA extraction.

\section{DNA Extraction}

Five-gram of tissue truffles fruit body samples was mixed in liquid nitrogen in a ceramic mortar and grounded with a pestle to a powder. DNA extraction kit was used, EZ-10 spin column fungal genomic DNA (Bioneer Corporation, South Korea). The company protocol for DNA extraction was followed. The final DNA products were kept at $-20^{\circ} \mathrm{C}$ to do further test.

\section{PCR Assay}

The internal transcribed spacer region of ribosomal DNA (ITS) was amplified by using ITS primer ITS1-F (TCC GTA GGT GAA CCT GCG G) and ITS4-R (TCC TCC GCT TAT TGA TAT GC) [27] (Bioneer Co, Korea). Total $20 \mu \mathrm{L}$ volume of PCR reaction mix were amplified using a thermo-cycler model (My ${ }^{\mathrm{TM}}$ Genie 32 Thermal Block- Bioneer, South Korea). The PCR reaction was performed in 20 total volumes consisting of $5 \mu \mathrm{L}$ of PCR PreMix (Bioneer Corporation, South Korea), and $5 \mu \mathrm{L}$ of DNA $(50 \mathrm{ng})$ template, and $3 \mu \mathrm{L}$ of primer ITSl-F, and $3 \mu \mathrm{L}$ ITS4-R, and $4 \mu \mathrm{L}$ of PCR demonized water. The following program settings were used: initial denaturation $\left(95^{\circ} \mathrm{C}, 2 \mathrm{~min}\right), 35$ cycles of denaturation $94^{\circ} \mathrm{C}$ for 30 s, annealing $\left(55^{\circ} \mathrm{C}, 1 \mathrm{~min}\right)$ and extension $\left(72^{\circ} \mathrm{C}, 1 \mathrm{~min}\right)$, final extension phase was performed at $72^{\circ} \mathrm{C}$ during $10 \mathrm{~min}$.
The PCR final products were loaded in a $1.5 \%$ agarose gel with Ethidium- bromide dye. DNA marker 100 bp was used (Bioneer Co., South Korea). Samples of $2 \mu \mathrm{L}$ mix with $2 \mu \mathrm{L}$ of $6 \mathrm{X}$ loading buffer and loaded in to the gel. Electrophoresis (model Bioneer Co., South Korea) was run at $80 \mathrm{~V}$ for $2 \mathrm{~h}$. The DNA bands were visualized and photographed using special UV camera (model AE-9000 E-Graph Atto-Jaban).

\section{DNA Sequencing and Data Analysis}

The PCR products were purified using the AccuPrep ${ }^{\circledR}$ PCR Purification Kit (Bioneer Co., South Korea) and sequenced commercially by facility at Bioneer Co., Korea. All sequenced data were blasted on NCBI nucleotide blast GenBank (www. blast.ncbi.nlm.nih.gov) [28] to reviewing the chromatograms, and any similarities above $98 \%$ from the data base were accepted to identify the species. All the sequences data were deposited in the NCBI gene bank and get accessions number. For the genetic diversity study, MAGA 6.06 [29] program was used to generate the phylogenic tree figure by using the ITS region sequence samples.

\section{RESULTS AND DISCUSSION}

\section{Morphology and Molecular Characterization}

All truffle samples collected in this study showed a wide diversity of morphology characteristics as in color gradients of the fruit body, and core texture and pattern (Figure 2). These characteristics are one of main criteria to the morphology classification for truffles species [31]. Sometime of these characteristic especially fruit body color can be changeable depends on temperature, moisture and the soil chemical and physical properties. The diversity on color and texture pattern for the fruit body can be very tricky even to the specialists to classify the species of the truffles. Also we found the truffles ascocarps inseparable with Helianthemum spp plants Figure 3. Fortas and Chevalier [25] report that species of Tirmania and Terfezia is known as mycorrhizal associated with genus Helianthemum.

Sequencing results of the ITS region, final alignment were 615 and $650 \mathrm{bp}$, confirmed the identity of samples to be among the Tirmania pinoyi and Terfezia claveryi species group (all identities $>98 \%$ sequence similarity). Samples sequences were blasted in the NCBI GenBank to compare the alignment with the GenBank sequences. The results showed that 4 samples were belong to T. pinoyi and 28 samples belong to T. claveryi from total 32 samples collected in this study. All the sequences were deposited in the NCBI GenBank and accession numbers were issued for all sequences start with MK478851 to MK910038 (Table 1). Many previous studies used the sequence of ITs region to identify truffles species $[5,32]$.

This results disagree with previous study survey on truffles in Iraq done by Abdullah et al [10] who reported five hypogeous ascomycotina in Iraq Terefezia boudieri, T.claveryi, Tirmania nivea, T.pinoyi and Phaeangium lefebvrei. Climate change may 


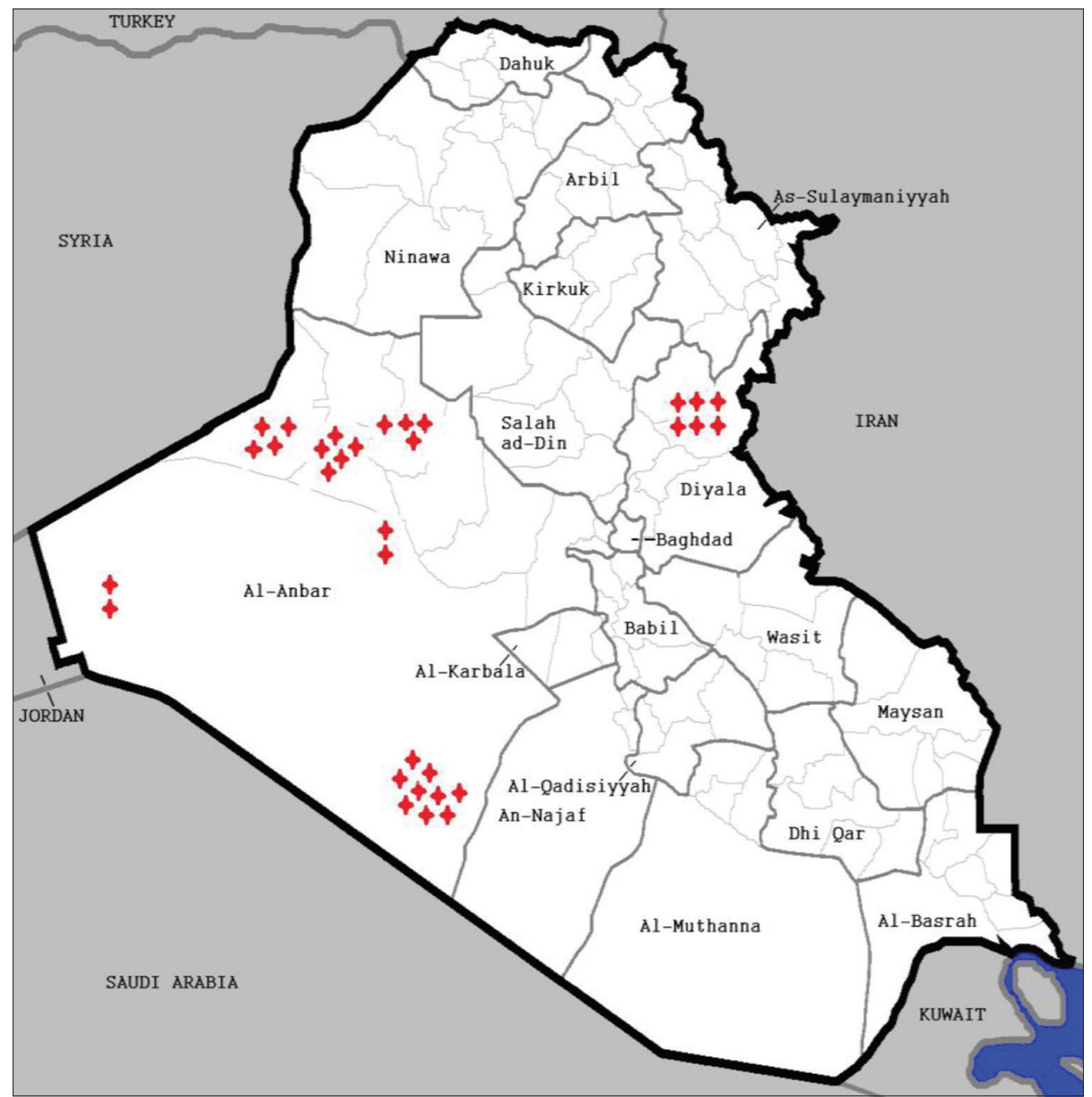

Figure 1: Sites of truffles sampling collected in this study from Iraq truffles habitats, every red star mean sample present

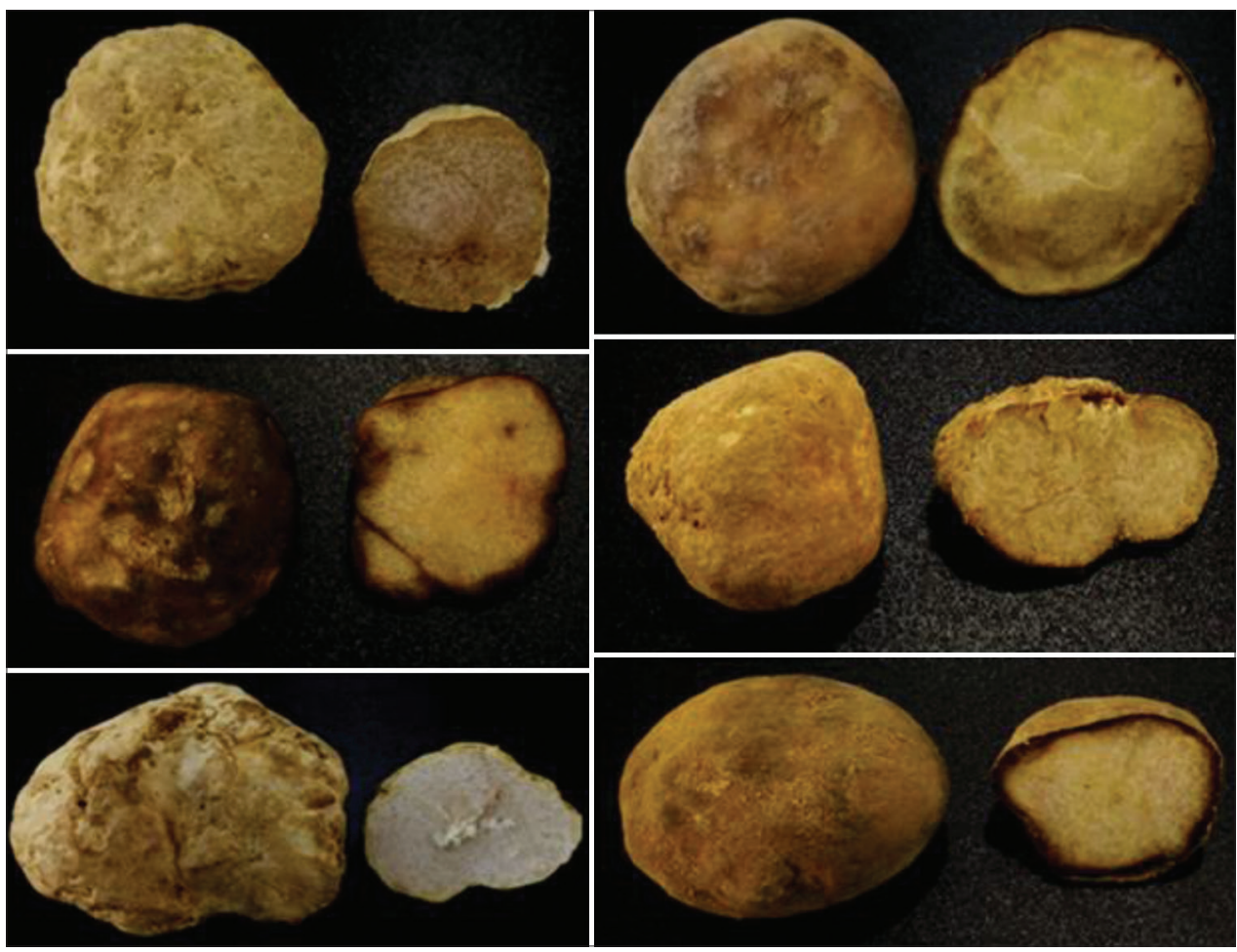

Figure 2: Truffles samples collected in this study show the morphological diversity in shape, core texture, and color 
Table 1: Truffles species found in this study and some accession sequences download from NCBI GenBank use to generate phylogenic tree

\begin{tabular}{|c|c|c|c|c|}
\hline Sample N0. & Location & Fruit body color & Species & Accession number \\
\hline 1 & Iraq-Rawa & White-light brown & Tirmania pinoyi & MK478851 \\
\hline 2 & Iraq-Rawa & White-light brown & T. pinoyi & M K478852 \\
\hline 3 & Iraq-Rawa & Light-brown & T. claveryi & MK478853 \\
\hline 4 & Iraq-Rawa & Dark-brown & T. claveryi & MK478854 \\
\hline 5 & Iraq-Alnakhab & Dark-brown & T. claveryi & M K478855 \\
\hline 6 & Iraq-Alnakhab & Dark-brown & T. claveryi & MK478856 \\
\hline 7 & Iraq-Alnakhab & Dark-brown & T. claveryi & MK478857 \\
\hline 8 & Iraq-Alnakhab & Dark-brown & T. claveryi & MK478858 \\
\hline 9 & Iraq-Alnakhab & Dark-brown & T. claveryi & MK478859 \\
\hline 10 & Iraq-Alnakhab & Dark-brown & T. claveryi & MK478860 \\
\hline 11 & Iraq-Alnakhab & Dark-brown & T. claveryi & MK478861 \\
\hline 12 & Iraq-Alnakhab & Dark-brown & T. claveryi & MK478862 \\
\hline 13 & Iraq-Alnakhab & White-light brown & T. pinoyi & MK478863 \\
\hline 14 & Iraq-Alnakhab & White-light brown & T. pinoyi & MK478864 \\
\hline 15 & Iraq-Ana & White-light brown & T. claveryi & M K880339 \\
\hline 16 & Iraq-Ana & White-light brown & T. claveryi & M K880340 \\
\hline 17 & Iraq-Ana & White-light brown & T. claveryi & M K880341 \\
\hline 18 & Iraq-Ana & White-light brown & T. claveryi & M K880342 \\
\hline 19 & Iraq-Ana & White-light brown & T. claveryi & M K880343 \\
\hline 20 & Iraq-Hadeetha & White-light brown & T. claveryi & M K880344 \\
\hline 21 & Iraq-Hadeetha & White-light brown & T. claveryi & M K880345 \\
\hline 22 & Iraq-Hadeetha & White-light brown & T. claveryi & M K880346 \\
\hline 23 & Iraq-Alrhatbua & White-light brown & T. claveryi & MK880347 \\
\hline 24 & Iraq-Alrhatbua & White-light brown & T. claveryi & M K880348 \\
\hline 25 & Iraq-Fallouja & White-light brown & T. claveryi & M K880349 \\
\hline 26 & Iraq-Fallouja & White-light brown & T. claveryi & M K880350 \\
\hline 27 & Iraq-Kahlar & Dark-brown & T. claveryi & MK910033 \\
\hline 28 & Iraq-Kahlar & Dark-brown & T. claveryi & MK910034 \\
\hline 29 & Iraq-Kahlar & Dark-brown & T. claveryi & MK910035 \\
\hline 30 & Iraq-Kahlar & Dark-brown & T. claveryi & MK910036 \\
\hline 31 & Iraq-Kahlar & Dark-brown & T. claveryi & MK910037 \\
\hline 32 & Iraq-Kahlar & Dark-brown & T. claveryi & MK910038 \\
\hline \multicolumn{5}{|c|}{ Reference sequences } \\
\hline 33 & Iran & _- & T. pinoyi & MH084953 \\
\hline 34 & Iran & _ & T. pinoyi & GQ228094 \\
\hline 35 & Spain & _ & T. pinoyi & MG917773 \\
\hline 36 & Slovenia & _ & T. pinoyi & FN395012 \\
\hline 37 & France & _ & T. pinoyi & AF276669 \\
\hline 38 & Hungary- & _ & T. claveryi & HQ698074 \\
\hline 39 & Spain & _ & T. claveryi & AF387647 \\
\hline 40 & Hungary & _ & T. claveryi & HQ698071 \\
\hline 41 & Spain & _ & T. claveryi & MN326673 \\
\hline 42 & Iran & _ & T. claveryi & GQ888693 \\
\hline 43 & Iran & _ & T. claveryi & EU519461 \\
\hline 44 & Tunisia & _ & T. claveryi & GU474801 \\
\hline 45 & Tunisia- & _ & T. claveryi & GU474804 \\
\hline 46 & Southern African & _ & T. claveryi & AF301421 \\
\hline 47 & Algeria & _ & T. claveryi & MF940189 \\
\hline 48 & Algeria & _- & T. claveryi & MF940197 \\
\hline 49 & Hungary & _- & T. claveryi & HQ698076 \\
\hline 50 & Hungary & _- & T. claveryi & HQ698072 \\
\hline 51 & Spain & _ & T. claveryi & MN326672 \\
\hline 52 & Spain & _- & T. claveryi & MN326671 \\
\hline 53 & Hungary & _- & T. claveryi & HQ698086 \\
\hline 54 & France & - & T. claveryi & AF276670 \\
\hline 55 & France & _ & T. claveryi & AF387645 \\
\hline 56 & Algeria & _ & T. claveryi & MF940182 \\
\hline 57 & Algeria & _ & T. claveryi & MF940186 \\
\hline 58 & Algeria & _ & T. claveryi & MF940185 \\
\hline 59 & Iran & _ & T. claveryi & GQ228093 \\
\hline 60 & Tunisia & _ & T. claveryi & GU474805 \\
\hline 61 & Iran & 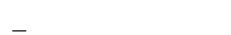 & T. pinoyi & GQ888695 \\
\hline
\end{tabular}




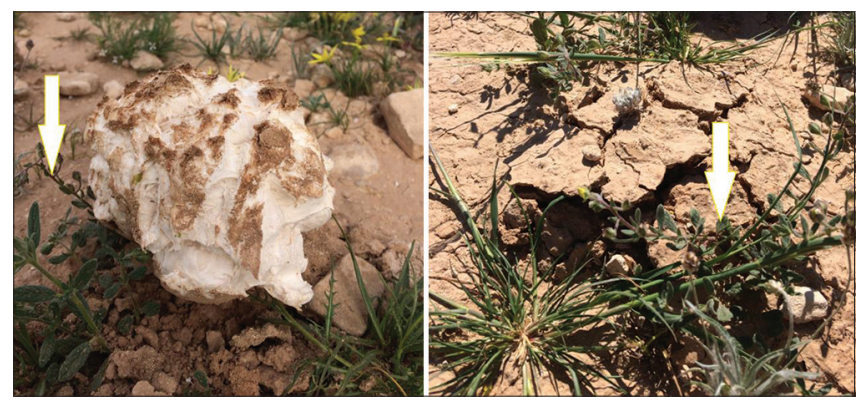

Figure 3: Right picture represent swelling of the ground for T. claveryi, ascocarp. Left picture represent $T$. pinoyi ascocarp over soil surface. White arrow shows Helianthemum spp plants

be a big factor for disappearance for some species and change the microflora, or the molecular identification is more accurate compare to the morphological identification that depend on the morphology characteristics.

\section{Genetic diversity study}

The Neighbor-Joining method used in this study to show the genetic diversity of the truffles species collected from the different geographic area. The ITS region sequencing of 32 sequence were use in this analyses, also 29 random sequence downloaded from NCBI GenBank website used as reference sequence belong to T. pinoyi and T. claveryi species selected from different bioclimatic zone countries that considered as habitat for truffles. These sequences were used as a reference to generating the phylogenic tree using MEGA6 software $[29,30]$.

The phylogenetic analysis result revealed that there is a two major groups A and B for the ITS sequences of the species in this study. Two subgroups under (B group) bl and b2 Figure 4. Two T. claveryi isolate MK478854 and MK910038 were identified to be in group A cluster, isolate MK478854 were alimented is same group with sequences references from Algeria and Hungary as one cluster, and sample MK910038 was alimented with the Spain sequence reference. The isolate sequence MK880350, MK880348, MK880339, MK478860, MK478855, MK478857, MK478861, MK880347, MK880349, and MK910034 of T. claveryi were clustered as a clade under subgroup b2 and aliment with Spanish and Hungarian sequence references. While sample MK880345, MK910037, MK880340, MK478858, MK910036, MK478853, MK88034land MK880343 were clustered in a group under b2 cluster alimented with the Iranian and Tunisian sequence references. The samples MK880346 and MK910033 were very unique clade under the subgroup bl were alimented with sequence references from four different countries Hungary, France, Iran, and South Africa belong to three continents Asia, Africa, and Europe. Samples sequences for MK478856, MK880342, MK910035, MK478862, MK880344, and MK478859 belong for T. claveryi species were separated in clade under subgroup bl with no sequence references match to it Figure 2, that keeps these truffles isolates possible to be a unique races belong to Iraqi habitat. A unique cluster of four T. pinoyi sequences under subgroup bl that not matching with

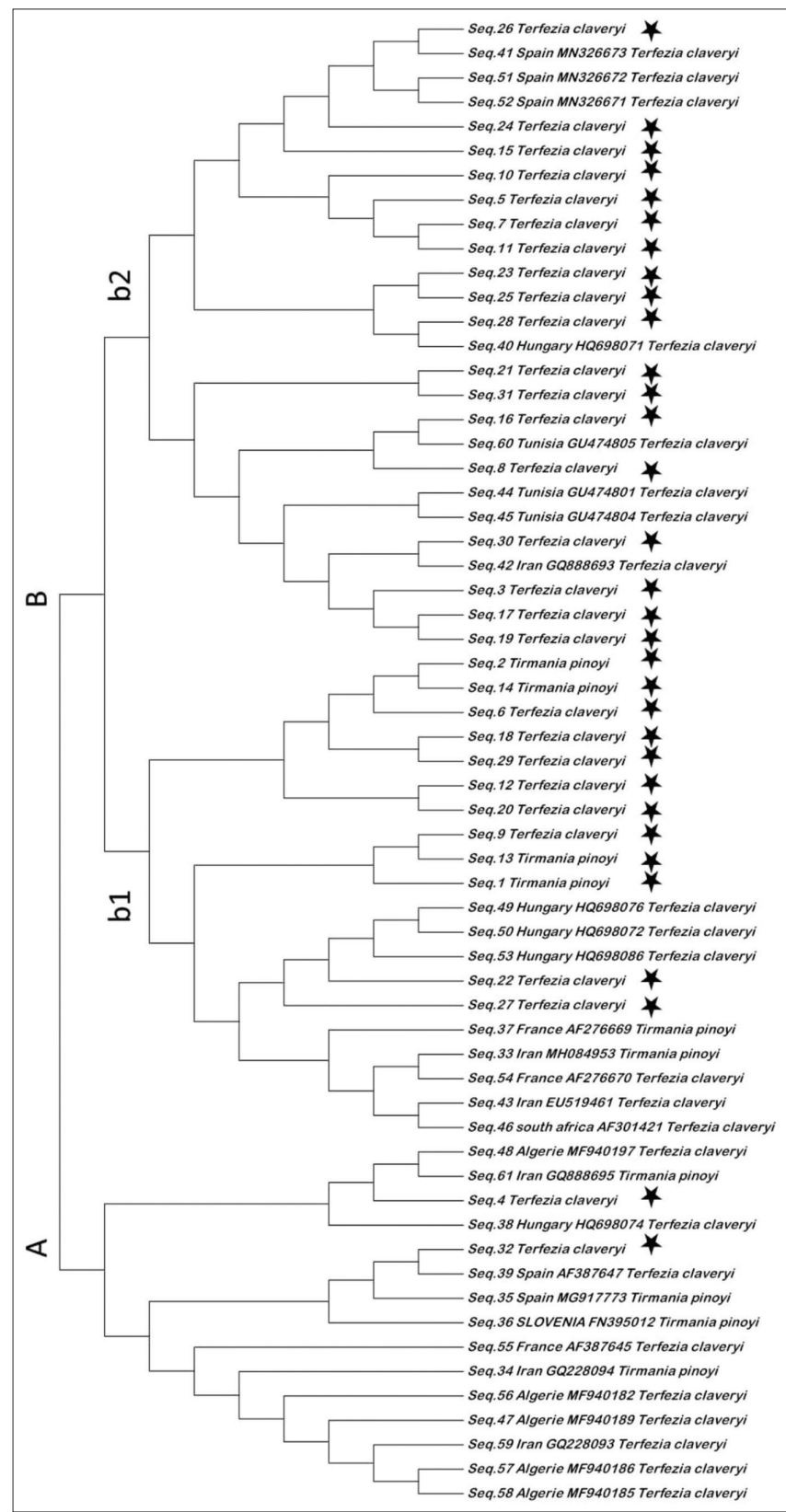

Figure 4: Neighbor-Joining phylogenic tree of 32 of Iraqi truffles samples using the ITS sequencing region and the reference sequences from NCBI GenBank

any reference sequences, which give a strong evidence to be possible unique a races, belong to the Iraqis habitat. Similar phylogenic study has been done by Bouzadi et al [5] in Libya, results showed all samples of Libyan truffle sequences were separated in a unique cluster, genetically far from the reference sequences, this approve a low genetic diversity for the individual separated glades. Also a previous study showed high genetic diversity for T. claveryi in Tunisia among the other species [14]. Diez et al [26] found a close genetic relationship between Tirmania and Terfezia by phylogenetic analyses method, a single evolutionary lineage maybe arose from pezizalean fungi that developed in the hypogeous habit that adapted to heat and drought in Mediterranean ecosystems. 


\section{CONCLUSIONS}

The conclusion results from this study showed that Iraqi truffles have a wide genetic diversity compared to the global reference sequences obtained from the NCBI GenBank for this study. This study give an idea and strong evidence that Iraq truffles have a high genetic diversity for both species T. claveryi and T. pinoyi, also this study found a high intraspecific variation of both morphological characters compared to the rDNA ITS sequences. From a genetic perspective, this is the first study focus on molecular classification and genetic diversity for Iraqi truffles. This study opens the horizons for the scientist to do more deep research studies to understand the fitness of the center diversity of Iraqi truffles.

\section{REFERENCES}

1. Pegler DN. Useful fungi of the world: The poor man's truffles of Arabia and manna of the Israelites. Mycologist. 2002;16(1):8-9.

2. Honrubia M, Cano A, Molina-Nin irola C. Hypogeous Fungi from Southern Spanish Semi-arid Lands. Persoonia. 1992;14:647-653.

3. Al-Delaimy KS. Protein and Amino Acid Composition of Truffle. Canadian Institute of Food Science and Technology Journal. 1977;10(3):221-222.

4. Murcia MA, Martínez-Tomé M, Jiménez AM, Vera AM, Honrubia M, Parras P. Antioxidant Activity of Edible Fungi (Truffles and Mushrooms): Losses during Industrial Processing. Journal of Food Protection. 2002;65(10):1614-1622.

5. Bouzadi M, Grebenc T, Turunen O, Kraigher H, Taib H, Alafai A, Shamekh S. Characterization of natural habitats and diversity of Libyan desert truffles. 3 Biotech. 2017;7(5).

6. Bradal L, Bissati S, Chenchouni H. Étude Mycologique et BioEcologique de la Truffe Blanche du Desert (Tirmania nivea Desf. Trappe 1971) dans la Region de Oued M'ya (Ouargla, Sahara Algerien). Revue Des Bioressources. 2013;3(1):6-14.

7. Chatin MA. Nouvelle Contribution A L'histoire Botanique De La Truffe: Kamés (2) De Bagdad (Terfezia hafizi, T. metaxasi) Et De Smyrne (T. Leonis);-Parallele Entre les Terfaz Ou Kamés D'afrique Et D’Asie Et Les Truffes De France, Bulletin de la Société Botanique de France. 1892;39(1):10-20.

8. Malencon, G. Champignons hypoges du nord de I Airique- I Ascomycetes. Persoonia. 1973;7:261-288.

9. Ewaz J, Nema JH. Taxonomic studies on three species of Truffles from Iraq. Journal of the Asiatic Society of Bangladesh, (Sci.). 1984:10:119-122.

10. Abdullah SK, Al-Issa A, Ewaz JO, Al-Bader SM. Taxonomy of edible hypogenous ascomycotina of Iraq. International journal of mycology and lichenology. 1989;4:9-21

11. Owaid MN. Biodiversity and bioecology of Iraqi desert truffles (Pezizaceae) during season 2014. Journal of Aridland Agriculture. 2016;2: 22 .

12. Al-jaff BA, Amin MA. Mycorrhizal synthesis between the truffle Terfezia claveryi and Some Annual dicot plants using different culture media. Journal of Zankoy Sulaimani - Part A, $2^{\text {nd }}$ Int.Conf.AGR (Special Issue). 2018;589-602.

13. Trappe JM. In: M. Bencivenga and B. Granetti, (eds.) Atti del secondo congresso internazionale sul tartufo. Spoleto, Italy. Com. Mont. Dei Martini, Italy Pub; 1988

14. Sbissi I, Ghodhbane-Gtari F, Neffati M, Ouzari H, Boudabous A, Gtari M. Diversity of the desert truffle Terfezia boudieri Chatin. in southern Tunisia. Canadian Journal of Microbiology. 2011;57(7):599-605.

15. Bradai L, Bissati S, Chenchouni H. Desert truffles of the North Algerian Sahara: Diversity and bioecology. Emirates Journal of Food and Agriculture. 2014;26(5):425.

16. Kiraly I, Bratek Z. Terfezia terfezioides a common truffle in Hungary. Micologiae Vegetazione Mediterranea. 1992;7:303-304

17. Lawrynowicz M, Markowić M, Milenković M, Ivanćević B. Terfezia terfezioides - a new hypogeous fungus for Balkan Peninsula. Acta Mycologica. 2014;32(2):233-238.

18. Zhang, BC. Chinese hypogeous mycoflora: Terfeziaceae, new species and new records. Micologiae Vegetazione Mediterranea. 1992; 7(1): 39-42.

19. Marasas WFO, Trappe JM. Notes on Southern African Tuberales. Bothalia. 1973;11 (12):139-141.

20. Ferdman Y, Aviram S, Roth-Bejerano N, Trappe JM, Kagan-Zur V. Phylogenetic Studies of Terfezia pfeilii and Choiromyces echinulatus (Pezizales) support new genera for southern African truffles: Kalaharituber and Eremiomyces. Mycological Research. 2005; 09(2):237-245.

21. Francis AA, Bougher NL. Historical and current perspectives in the systematics of Australian cortinarioid sequestrate (truffle-like) fungi. Australsian Mycologist. 2002; 21(3):81-93.

22. Lebel T, Castellano MA. Australasian truffle-like fungi. IX. History and current trends in the study of the taxonomy of sequestrate macrofungi from Australia and New Zealand. Australian Systematic Botany. 1999;12(6):803

23. Trappe JM, Castellano MA. Keys to the genera of truffles (Ascomycetes). Mcllvainea. 1991;10: 47-65.

24. Izzo AD, Meyer M, North M, Trappe JM, Bruns TD. Hypogeous ectomycorrhizal fungal species on roots and in small mammal diet in a mixed conifer forest. Forest Science. 2005;53(3):243-254.

25. Fortas Z, Chevalier G. Effet des conditions de culture sur lamycorhization de I'Helianthemum guttatum par trois espces de terfez des genres Terfezia et Tirmania d' Algerie. Canadian Journal of Botany. 1992;70:2453-2460

26. Diez J, Manjon JL, Martin F. Molecular Phylogeny of the Mycorrhizal Desert Truffles (Terfezia and Tirmania), Host Specificity and Edaphic Tolerance. Mycologia. 2002;94 (2):247.

27. White TJ, Bruns T, Lee S, Taylor J. Amplification and direct sequencing of fungal ribosomal RNA genes for phylogenetics. PCR protocols. 1990;315-322.

28. Altschul, SF, Gish W, Miller W, Myers EW, Lipman DJ. Basic local alignment search tool. Journal of Molecular Biology. 1990;215:403-410.

29. Tamura K, Stecher G, Peterson D, Filipski A, Kumar, S. MEGA6: Molecular Evolutionary Genetics Analysis version 6.0. Molecular Biology and Evolution. 2013;30:2725-2729. doi: 10.1093/molbev/ mst197

30. Tamura K, Nei M, Kumar S. Prospects for inferring very large phylogenies by using the neighbor-joining method. Proceedings of the National Academy of Sciences (USA):; 2004

31. Trappe M, Michael AC. Keys to the genera of truffles (Ascomycetes). Department of Forest Science, Oregon State University, P 1-18;2007.

32. Zitounl-Haouar FH, Carlavilla JR, Moreno G, Manjón JL, Fortas Z Genetic diversity of the genus Terfezia (Pezizaceae, Pezizales): New species and new record from North Africa. Phytotaxa. 2018:334(2):183 